\title{
Teresa Lubińska
}

Uniwersytet Szczeciński

e-mail: tlreadgene@gmail.com

\section{Jarosław Marczak}

Uniwersytet Łódzki

e-mail: marczak.jaroslaw@gmail.com

\section{REGULACJE PRAWNE, INSTYTUCJE FISKALNE ORAZ WYDATKI PUBLICZNE POLSKI I HISZPANII W MAKROZARZĄDZANIU STABILNOŚCIĄ FINANSÓW PUBLICZNYCH}

\section{LEGAL REGULATIONS, FISCAL INSTITUTIONS AND PUBLIC EXPENDITURE OF POLAND AND SPAIN IN THE MACRO-MANAGEMENT OF PUBLIC FINANCES STABILITY}

DOI: $10.15611 /$ pn.2018.521.10

JEL Classification: H20, H30, H60, H62

Streszczenie: Problematyka makrozarządzania stabilnością finansów publicznych obejmuje wiele zagadnień. Ważnym aktem jest tzw. pakt fiskalny, czyli Traktat o Stabilności, Koordynacji i Zarządzaniu w UE. Realne osiągnięcia państw UE w zakresie procedury nadmiernego deficytu są bardzo zróżnicowane. Przykładem jest Polska i Hiszpania. W artykule przedstawiono sytuację fiskalną obu państw oraz dokonano analizy porównawczej fiskalnych regulacji prawnych i instytucjonalnych, które były wykorzystane w działaniach makrozarządzania stabilnością finansów publicznych. Wyniki badań wskazują na dużą restrykcyjność narzędzi fiskalnych w Polsce na tle Hiszpanii na poziomie zarówno rządowym, jak i samorządowym.

Słowa kluczowe: makrozarządzanie, finanse publiczne, stabilność, wydatki publiczne, instytucje fiskalne, Polska, Hiszpania.

Summary: Macro-management of public finance stability covers several aspects. Fiscal pact - The Stability, Coordination and Governance Treaty is an important act. The real achievements of excessive deficit procedure are variable. An example is Poland and Spain. In this article fiscal situation of both countries was studied and comparison of fiscal law regulation and fiscal institutions was performed. The results of studies indicate higher level of restrictions in Poland in comparison to Spain. However, fiscal pact imposed the increase of fiscal restrictions also in Spain.

Keywords: macro-management, public finances, stability, public expanditures, fiscal institutions, Poland, Spain. 


\section{Wstęp}

Modele funkcjonowania finansów publicznych (fp) determinowane są rozwiązaniami ustrojowymi, które są zróżnicowane w poszczególnych krajach. Różnorodność ta widoczna jest nie tylko gdy porównuje się państwa federalne na tle państw unitarnych, lecz również wewnątrz tych dwóch grup państw. Polska jest krajem unitarnym, tzn. że w całym kraju obowiązuje jednolite prawo, podatki i polityka społeczno-gospodarcza. W strukturze władzy samorządowej wyróżniamy gminy, powiaty oraz samorządy wojewódzkie, których samodzielność finansowa jest zróżnicowana i dość ograniczona. Hiszpania jest również państwem unitarnym, w którym obowiązuje jednolite prawo. Państwo to jest monarchią parlamentarną o bardzo szerokim zakresie decentralizacji, określanej mianem autonomii, najwyższego szczebla samorządu terytorialnego - samorządu regionalnego - wspólnot autonomicznych (las comunidades autónomas - CCAA) [por. Marczak 2013, s. 33]. W strukturze władzy samorządowej wyróżnia się gminy (los municipios), prowincje (las provincias)1 i wspomniane już regiony - wspólnoty autonomiczne. W przeciwieństwie do polskich rozwiązań, CCAA mają określony zakres władztwa wobec prowincji i gmin kraju. Fp w obu państwach unitarnych oparte są więc na zróżnicowanych modelach decentralizacji władzy. Szczególnym zadaniem publicznym o statusie zadania ogólnego jest makrozarządzanie stabilnością finansów publicznych. Stabilność fp rozumiana jest najczęściej jako zdolność do regulowania zobowiązań w ujęciu rocznym i długoterminowym i utożsamiana jest $\mathrm{z}$ instrumentami polityki fiskalnej. Głównymi kryteriami oceny stabilności fp są wynik i dług Sektora Instytucji Rządowych i Samorządowych (SIRziS). Od kilku lat relacje długu publicznego do PKB w Hiszpanii przekraczają 90\%, a w Polsce nie przekraczają 55\% PKB. Z uwagi na tak znaczne różnice w kształtowaniu się wartości wskaźników wyniku i długu SIRziS w relacji do PKB podjęto próbę oceny głównych regulacji prawnych, instytucji fiskalnych oraz innych czynników wykorzystanych do makrozarządzania stabilnością fp, co oznacza szersze, również pozafiskalne podejście do finansów publicznych.

Celem artykułu jest:

- określenie znaczenia terminu „stabilność fp”,

- charakterystyka SIRziS Polski i Hiszpanii na tle zasady decentralizacji,

- określenie regulacji prawnych i instytucji odnoszących się do stabilności fp,

- ukazanie sytuacji fiskalnej Polski i Hiszpanii w latach 2008-2015, z uwzględnieniem podziału na podsektor rządowy i samorządowy oraz kluczowych zmian w strukturze wydatków w latach 2008-2015,

- sformułowanie uwag i wniosków dotyczących działań w obszarze makrozarządzania stabilnością fp.

1 Gminy i prowincje określane są mianem jednostek lokalnych - las entidades locales - EELL lub korporacji lokalnych - las corporaciones locales - CCLL. 
W artykule wykorzystano metodę analizy treści dokumentów, w tym krajowych aktów prawnych regulujących aspekty fiskalne i samorządowe oraz aspekty instytucjonalne sektora finansów publicznych w Polsce i w Hiszpanii. Zastosowano również metodę analizy porównawczej wybranych kategorii finansów publicznych.

\section{Pojęcie stabilności finansów publicznych}

Przegląd literatury z lat 2015-2017 wyraźnie wskazuje na skromny dorobek w obszarze szeroko rozumianej stabilności finansów publicznych. Przedmiotem rozważań jest natomiast zagadnienie zrównoważonego rozwoju w aspekcie instytucjonalnym czy dyskusja nt. głównych nurtów współczesnej makroekonomii (por. [Sukiennik, Dokurno, Fiedor 2017; Fiedor, Scheuer, Dokurno 2016]). Wzajemne relacje między zrównoważonym rozwojem i finansami publicznymi prezentuje praca M. Cieślukowskiego [2017].

Wskaźniki bezpośrednio związane ze stabilnością finansów publicznych są więc przedmiotem badań makroekonomicznych, skoncentrowanych na zależnościach między relacjami dochodów i wydatków do PKB a tempem wzrostu gospodarczego (por. [Redo 2017]). Aktualne makroekonomiczne i ważne spojrzenie na rolę ekonomii postkeynesowskiej, w tym ,aktywnego wspomagania popytu sektora prywatnego wydatkami publicznymi, przy utrzymaniu w ryzach relacji deficytu budżetowego i długu publicznego oraz kontroli państwa nad rynkami finansowymi i spekulacyjnymi przypływami kapitału", zawiera praca J. Osiatyńskiego [2016]. Z kolei ewolucję poglądów neoliberalnych w sferze ekonomicznej, ukierunkowaną na respektowanie idei wolności gospodarczej przy równoczesnej ochronie przed nadużyciami, które umożliwiają wykorzystanie niektórych uczestników rynku przez część podmiotów, prezentuje praca M. Ratajczaka [2017].

W wymienionych pracach w centrum rozważań są fp jako bardzo ważna składowa gospodarki, w tym deficyt i dług. W nurcie rozważań makroekonomicznych, które bliżej sytuują finanse publiczne w szeroko ujętym systemie finansowym i równocześnie definiują samo pojęcie stabilności systemu finansów publicznych w wąskim i szerszym ujęciu, należy wyróżnić prace A. Alińskiej [2017]. W wąskim ujęciu stabilność systemu fp identyfikowana jest $\mathrm{z}$ pojęciem zrównoważonej polityki fiskalnej - fiscal sustainability. Ujęcie to odpowiada powszechnie przyjętej definicji stabilności, czyli zdolności do spłaty zobowiązań w ujęciu rocznym i długoterminowym. W szerszym ujęciu stabilność systemu fp - public finance stability obejmuje następujące dodatkowe obszary aktywności:

- możliwość gromadzenia dochodów,

- kształtowanie optymalnej wartości długu publicznego,

- świadczenie usług w sektorze publicznym [Alińska 2017].

Dość częstym wątkiem badawczym jest drugi obszar, tzn. optymalizacja zarządzania długiem publicznym. Prace te skupione są na sposobach finansowania potrzeb pożyczkowych, które umożliwiają optymalizację struktury długu, w wymia- 
rze rynków i instrumentów finansowych czy terminów emisji. Wymienić należy pracę T. Uryszka, w której przedmiotem badań jest wskaźnik deficytu pierwotnego i luki podatkowej jako wskaźniki oceny poziomu równoważenia polityki fiskalnej fiscal sustainability (por. [Uryszek 2016]).

$\mathrm{Z}$ uwagi na fakt, że obszar badań public finance stability obejmuje również wątki instytucjonalne oraz ustrojowe, które w dużej mierze determinują strukturę wydatków oraz dochodów, uprawnione jest użycie w artykule terminu „makrozarządzanie stabilnością fp" jako zbliżonego do public finance stability.

\section{Charakterystyka SIRziS Polski i Hiszpanii w świetle zasady decentralizacji władzy}

O najważniejszej zasadzie ustrojowej, tzn. o zasadzie decentralizacji władzy publicznej, przesadzają art. art. 15, 16 oraz 167 Konstytucji RP. W art. 15 ust. 1 stwierdza się: Ustrój terytorialny Rzeczpospolitej Polski zapewnia decentralizację władzy publicznej. A w art. 16 ust. 2: Samorząd terytorialny uczestniczy w sprawowaniu władzy publicznej. Przysługującą mu w ramach ustawy istotną cześć zadań publicznych samorząd wykonuje w imieniu własnym i na własną odpowiedzialność (Konstytucja RP 1997). Zaś art. 167 ust. 1 ustawy zasadniczej jest następujący: Jednostkom samorządu terytorialnego zapewnia się udział $\mathrm{w}$ dochodach publicznych odpowiednio do przypadających im zadań. Natomiast dalej, w niniejszym artykule w ust. 4 następuje uzupełnienie definicji władztwa dochodowego o następujący zapis: Zmiany w zakresie zadań i kompetencji jednostek samorządu terytorialnego następują wraz z odpowiednimi zmianami w podziale dochodów publicznych.

Źródłami dochodów samorządowych są: dochody własne, dotacje oraz subwencje. Struktura dochodów w gminach, powiatach i samorządach wojewódzkich przesądza o skali decentralizacji władzy w Polsce w zakresie pobierania dochodów podatkowych. Wskaźniki decentralizacji władztwa podatkowego przesądzają zaś w znacznej mierze o poziomie samodzielności finansowej JST. Struktura dochodów JST zawarta w tab. 1 wyraźnie pokazuje średni poziom decentralizacji dochodów w JST w Polsce. W uzupełnieniu należy dodać, że dochody własne obejmują również udziały w podatkach PIT i CIT, które są podatkami centralnymi.

Tabela 1. Struktura dochodów samorządowych w Polsce w 2016 r. (w \%)

\begin{tabular}{|l|c|c|c|}
\hline \multicolumn{1}{|c|}{ Wyszczególnienie } & Gminy & Powiaty & Samorządy wojewódzkie \\
\hline Dochody własne & 44,3 & 35,4 & 53,4 \\
\hline Transfery & 55,7 & 64,6 & 46,6 \\
\hline
\end{tabular}

Źródło: opracowanie własne na podstawie [Gospodarka finansowa..., s. 59, 100].

W przypadku Hiszpanii zasada decentralizacji władzy publicznej wynika z zapisów Konstytucji Hiszpanii (CE). Możliwości oddziaływania rządu na wspólnoty 
autonomiczne są bardzo ograniczone. Artykuły 148 i 149 CE zawierają enumeratywne zakresy kompetencji CCAA oraz rządu (wyłączne, to znaczy nie mogą być przekazane CCAA). Do wyłącznych kompetencji rządu należą m.in. państwowe finanse publiczne i państwowy dług publiczny. W art. 156 ust. 1 zapisano, że CCAA cieszą się autonomią finansową dla rozwijania i wykonywania swoich kompetencji zgodnie z zasadą koordynacji z państwowymi finansami publicznymi i zasadą solidarności wszystkich Hiszpanów.

W tabeli 2 przedstawiono strukturę dochodów w samorządach w Hiszpanii za $2015 \mathrm{r}$.

Tabela 2. Struktura dochodów samorządowych w Hiszpanii w 2015 r. w \%

\begin{tabular}{|l|c|c|c|}
\hline \multicolumn{1}{|c|}{ Wyszczególnienie } & Gminy & Prowincje & Wspólnoty autonomiczne \\
\hline Dochody własne & 66 & 32 & 76,9 \\
\hline Transfery & 34 & 68 & 23,1 \\
\hline
\end{tabular}

Źródło: http://www.minhafp.gob.es/Documentacion/Publico/CDI/SGFAL/HHLL\%20en\%20cifras/ HHLL\%20en\%20cifras\%202015.pdf.

Powyższe dane wyraźnie wskazują na wysoki poziom samodzielności dochodowej wspólnot autonomicznych oraz gmin.

O samodzielności finansowej samorządów decydują również ich kompetencje w obszarze zaciągania zobowiązań finansowych oraz regulacje odnoszące się do skali zadłużenia. Z uwagi na fakt, że po kryzysie finansowym nastąpiły w obu krajach zmiany w dyscyplinowaniu finansów samorządowych, odpowiednio do regulacji tzw. konsolidacji fiskalnej państw UE, zagadnienie to wymaga uprzedniej prezentacji wymogów paktu fiskalnego UE.

\section{Instytucje fiskalne oraz regulacje sprawowania władzy w zakresie stabilności finansów publicznych w Polsce i w Hiszpanii}

W odniesieniu do państw UE, w tym oczywiście Polski i Hiszpanii, regulacje prawne, które mają na celu monitorowanie stabilności fp i zapobieganie nadmiernemu zadłużeniu się zawarte są w Pakcie fiskalnym UE z lat 2012/13.

Zasadniczo regulacje te obowiązywały również w latach poprzednich, jednak kryzys finansów publicznych, będący skutkiem kryzysu finansowego z 2008 r., zwiększył rangę procedury nadmiernego deficytu. Przekroczenie normy deficytu SIRziS powyżej 3\% PKB skutkuje koniecznością podjęcia działań naprawczych, które uporządkują sytuację fiskalną danego państwa. Nadzór nad procedurą nadmiernego deficytu sprawuje Komisja Europejska oraz Rada Unii. Rada wydaje zalecenia naprawcze oraz wyznacza ostateczny termin obniżenia deficytu SIRziS (General Government Deficit). Kraje UE będące w strefie euro, jeśli nie dostosują 
się do zaleceń Rady UE, mogą być obciążone opłatą w wysokości 0,2\% PKB. Zaś te, które nie są w strefie euro, mogą być narażone na utratę środków z Funduszu Spójności. Według rozporządzenia Rady UE państwa strefy euro opracowują programy stabilności finansów publicznych, a kraje pozostałe opracowują programy konwergencji. Jak podkreśla E. Chojna-Duch [2017, s. 346], zastosowanie sankcji opierać się ma na tzw. odwrotnej większości kwalifikowanej przy głosowaniu uchwały o sankcjach. Wzmocnienie norm stabilności finansów publicznych nastąpiło poprzez wprowadzenie dodatkowych narzędzi makrozarządzania. Są to:

- wzrost rangi wskaźnika długu SIRziS < 60\% PKB;

- wprowadzenie nowej reguły wydatkowej po przekroczeniu deficytu 3\% PKB, która formułuje regulację mówiącą, że wskaźnik średniorocznego wzrostu wydatków nie może przekroczyć wskaźnika średniorocznego wzrostu potencjalnego PKB;

- $\quad$ wprowadzenie sankcji za „szarą strefę” w statystyce SIRziS;

- wzrost znaczenia wieloletnich ram fiskalnych w planowaniu budżetowym.

Powyższe regulacje skoncentrowane są na narzędziach makrozarządzania równowagą fiskalną. Mimo wprowadzenia ww. nowych regulacji w polityce nadzoru państw UE, w tym w sferze euro, realne osiągnięcia w całej grupie państw są bardzo zróżnicowane, co widoczne jest na przykładzie Polski i Hiszpanii. Dodać należy, iż w ostatnich latach pojawiły się nowe, łagodniejsze interpretacje wyniku i długu SIRziS. Podjęto też wysiłki pobudzania wzrostu gospodarczego. Utworzono, przykładowo, ważny instrument prorozwojowy w postaci Europejskiego Funduszu Inwestycji Strategicznych (por. [Chojna-Duch 2017, s. 346]).

W Polsce odpowiedzialność za zarządzanie długiem publicznym przypisana jest Radzie Ministrów. Nie istnieje niezależny od władzy wykonawczej organ fiskalny. Artykuł 221 Konstytucji RP stwierdza: Inicjatywa ustawodawcza w zakresie ustawy budżetowej, ustawy o prowizorium budżetowym, zmiany ustawy budżetowej, ustawy o zaciąganiu długu publicznego oraz ustawy o udzieleniu gwarancji finansowych przez państwo przysługuje wyłącznie Radzie Ministrów (Konstytucja RP 1997).

Wskaźnik maksymalnego deficytu w relacji do PKB na poziomie 3\%, jako główny unijny parametr pomiaru stabilności finansów publicznych, adaptowany jest do gospodarek krajowych poprzez odpowiednie regulacje krajowe.

Do głównych narzędzi i procedur, które odnoszą się do monitorowania stabilności fp w Polsce, należy zaliczyć następujące regulacje prawne oraz instrumenty planowania strategicznego i wieloletniego:

- art. 216 Konstytucji RP ograniczający dług publiczny do 60\% PKB,

- art. 220 Konstytucji RP o braku uprawnień sejmu do zwiększania deficytu budżetu państwa w pracach nad projektem ustawy budżetowej,

- normy ostrożnościowe i procedury sanacyjne, związane z długiem, stanowiące rozdział $3 \mathrm{w}$ dziale II ustawy o finansach publicznych - ufp [Ustawa z 27 sierpnia 2009], 
- art. 165 ust 1. ufp, który stwierdza, że wydatki na obsługę długu skarbu państwa są dokonywane przed innymi wydatkami budżetu państwa. Wcześniej zapis ten w ustawie z 2005 r. zawierał art. 140,

- wprowadzona w 2015 r. nowa stabilizująca reguła wydatkowa - art. 112 ufp, która zawiera sankcje ograniczające poziom wydatków budżetowych w przypadku przekroczenia normy 3\% deficytu SIRziS do PKB oraz w przypadku przekroczenia norm ostrożnościowych długu publicznego,

- normy długu i rocznych zobowiązań w JST oraz indywidualne wskaźniki zobowiązań w JST. Do roku 2013 dług jednostek samorządu terytorialnego nie mógł przekroczyć 60\% dochodów, a roczne zobowiązania 15\% dochodów. Od 2014 r. obowiązują rygorystyczne limity zobowiązań dla JST wg art. 243 ufp, stanowiące ocenę zdolności kredytowej opartej na nadwyżce bieżącej i dochodach majątkowych.

Poza obowiązkowym 4-letnim programem konwergencji, który od 2015 r. jest składową Wieloletniego Planu Finansowego Państwa (WPFP), zgodnie z art. 75 ufp opracowywana jest czteroletnia Strategia Zarządzania Długiem Skarbu Państwa. Wraz z uzasadnieniem dołączana jest do projektu ustawy budżetowej. Do roku 2008 Strategia Zarządzania Długiem obejmowała prognozę na 3 lata. WPFP zobowiązuje do sformułowania priorytetów rozwojowych w sferze wydatków publicznych i dochodów fiskalnych.

Na poziomie samorządów od 2011 r. opracowywane są Wieloletnie Prognozy Finansowe (WPF), które obejmują okres roku budżetowego oraz co najmniej trzech kolejnych lat. Prognozę kwoty długu w samorządach, która dołączana jest do WPF, opracowuje się na okres, na który zaciągnięto lub planuje się zaciągnąć zobowiązania.

Wymienione regulacje należy widzieć zarówno w świetle nadzoru fiskalnego, jak i wymogów prorozwojowych co do wydatków w Polsce tak na poziomie rządowym, jak i samorządowym.

W Hiszpanii, na podstawie ustawy LOFCA [Ustawa 8/1980], która reguluje finansowanie wspólnot autonomicznych, powołano Radę Polityki Fiskalnej i Finansowej (El Consejo de Política Fiscal y Financiera - CPFF). To ciało ma decydujące znaczenie $w$ zakresie całości finansów publicznych oraz prowadzonej polityki fiskalnej. CPFF działa na podstawie regulaminu zatwierdzonego przez większość absolutną głosów członków, którymi są Minister Finansów i Administracji Publicznych oraz ministrowie (radcy) finansów rządów regionalnych, wszyscy z równymi głosami.

Rada spełnia m.in. następujące zadania:

- koordynacja polityki budżetowej CCAA i państwa;

- przekazywanie informacji i przyjmowanie umów przewidzianych w Ustawie organicznej uzupełniającej Ustawą ogólną o stabilności budżetowej;

- koordynacja polityki zadłużenia;

- koordynacja polityki inwestycji publicznych. 
Nie istnieją konstytucyjne zapisy limitujące wielkość długu publicznego ${ }^{2}$. W związku z dynamicznymi przyrostem długu w 2011 r., mimo że obowiązywały wcześniej (od 2001 r.) określone przepisy i procedury dotyczące stabilności budżetowej ${ }^{3}$, wprowadzono zmiany w Konstytucji Hiszpanii. Artykuł 135 Konstytucji składał się pierwotnie z dwóch ustępów. Po zmianie tego artykułu znalazło się ich sześć. Na uwagę zasługuje objęcie odpowiedzialnością za stan finansów publicznych wszystkich podmiotów publicznych: rządu, CCAA i EELL. Szczegółowe kwestie są następujące: podporządkowanie działań zasadzie stabilności budżetowej; ustalenie deficytu strukturalnego dla państwa i CCAA ustawą organiczną (akt prawny najwyższej rangi) zgodnie z regulacjami unijnymi, EELL tworzą budżety zrównoważone; zaciągnięcie długu publicznego przez państwo i CCAA wyłącznie na mocy ustawy, środki na jego obsługę (odsetki i kapitał) ujęte w wydatkach budżetowych bez możliwości ich zmiany oraz nadaje się priorytet w regulowaniu zadłużenia; ustalono, że wysokość długu publicznego wszystkich administracji publicznych nie może przekroczyć wartości referencyjnej ustalonej w Traktacie o funkcjonowaniu UE; odstępstwa od przyjętych restrykcji będą możliwe jedynie w przypadku klęsk żywiołowych, recesji gospodarczej lub nadzwyczajnych sytuacji, które wymknęły by się spod kontroli państwa i znacząco zaszkodziłyby sytuacji finansowej lub gospodarczej lub społecznej stabilności państwa; ustawą organiczną określi się podział deficytu i limitów zadłużenia między różnymi administracjami publicznymi, metodologię i procedurę obliczania deficytu strukturalnego i odpowiedzialność z tytułu nieosiągnięcia stabilności budżetowej; CCAA mają wprowadzić do swojego porządku prawnego odpowiednie regulacje umożliwiające skuteczne stosowanie zasady stabilności budżetowej.

W 2013 r. została powołana ustawą organiczną [Ustawa organiczna nr 6/2013] nowa instytucja - Niezależny Urząd ds. Odpowiedzialności Fiskalnej, którego celem jest zagwarantowanie skutecznego przestrzegania przez administracje publiczne zasady stabilności budżetowej przewidzianej w art. 135 Konstytucji Hiszpańskiej, poprzez ciągłą ocenę cyklu budżetowego, zadłużenia publicznego oraz analizy prognoz ekonomicznych (art. 2). Należy podkreślić, że urząd ten jest całkowicie niezależny od jakichkolwiek instytucji publicznych czy prywatnych. Ma zagwarantowane dostateczne środki na swoją działalność.

2 Hiszpańska Konstytucja odwołuje się, w przeciwieństwie do polskiej, do umów międzynarodowych, co ułatwia wprowadzanie wszelkich zmian, jeśli zajdą, bez „ruszania” Konstytucji.

3 Ustawa 18/2001. Bezpośrednim impulsem do takiego działania było posiedzenie Rady Europy w czerwcu 2000 r., na którym wezwano państwa członkowskie nie tylko do wzmocnienia działań zawartych w Pakcie Stabilności i Wzrostu, ale także wykraczających poza ten pakt [Femia Julve 2015]. Należy także podkreślić, że od 1999 r. są w Hiszpanii opracowywane czteroletnie Programy Stabilności (El Programa de Estabilidad 2018-2021), co roku aktualizowane. Ponadto tworzone są inne programy, np. Strategie Polityki Fiskalnej (Estrategia del Política Fiscal 2018). 


\section{Wybrane parametry oceny sytuacji fiskalnej Polski i Hiszpanii}

W tabelach 3, 4 i 5 przedstawiono wskaźniki: fiskalizmu (tax revenue - podatki i składki); wskaźniki redystrybucji; poziom luki fiskalno-redystrybucyjnej oraz relacje wyniku i długu SIRziS do PKB. Parametry te pozwalają przeprowadzić ogólną analizę porównawczą sytuacji fiskalnej Polski i Hiszpanii.

Tabela 3. Wskaźniki fiskalizmu w \% PKB

\begin{tabular}{|l|c|c|c|c|c|c|c|c|}
\hline \multicolumn{1}{|c|}{ Państwo } & 2008 & 2009 & 2010 & 2011 & 2012 & 2013 & 2014 & 2015 \\
\hline Polska & 34,8 & 31,9 & 32,1 & 32,6 & 32,8 & 32,7 & 32,8 & 33,2 \\
\hline Hiszpania & 32,7 & 30,4 & 32,0 & 31,9 & 32,9 & 33,8 & 34,4 & 34,4 \\
\hline
\end{tabular}

Źródło: [Eurostat 2016].

Tabela 4. Wskaźniki redystrybucji w \% PKB

\begin{tabular}{|l|c|c|c|c|c|c|c|c|}
\hline \multicolumn{1}{|c|}{ Państwo } & 2008 & 2009 & 2010 & 2011 & 2012 & 2013 & 2014 & 2015 \\
\hline Polska & 44,2 & 44,9 & 45,7 & 43,8 & 42,7 & 42,4 & 42,1 & 41,5 \\
\hline Hiszpania & 41,1 & 45,8 & 45,6 & 45,8 & 48,1 & 45,6 & 44,9 & 43,8 \\
\hline
\end{tabular}

Źródło: [Eurostat 2016].

Tabela 5. Luka fiskalno-redystrybucyjna

\begin{tabular}{|l|c|c|c|c|c|c|c|c|}
\hline $\begin{array}{c}\text { Luka (wskaźnik redystrybucji } \\
\text { - wskaźnik fiskalizmu) }\end{array}$ & 2008 & 2009 & 2010 & 2011 & 2012 & 2013 & 2014 & 2015 \\
\hline Polska & 9,4 & 13,0 & 13,6 & 11,2 & 9,9 & 9,7 & 9,3 & 8,3 \\
\hline Hiszpania & 8,4 & 15,4 & 13,6 & 13,9 & 15,2 & 11,8 & 10,5 & 9,4 \\
\hline
\end{tabular}

Źródło: opracowanie własne.

Tabela 6. Deficyt i dług SIRziS Polski i Hiszpanii w latach 2008-2016

\begin{tabular}{|l|c|c|c|c|c|c|c|c|c|}
\hline \multicolumn{1}{|c|}{ Wyszczególnienie } & 2008 & 2009 & 2010 & 2011 & 2012 & 2013 & 2014 & 2015 & 2016 \\
\hline $\begin{array}{l}\text { Wynik SIRziS Polska } \\
\text { \% PKB }\end{array}$ & $-3,6$ & $-6,8$ & $-7,9$ & $-5,1$ & $-3,9$ & $-4,3$ & $-2,8$ & $-2,6$ & $-2,4$ \\
\hline $\begin{array}{l}\text { Wynik SIRziS Hiszpania } \\
\% \text { PKB }\end{array}$ & $-4,5$ & $-11,1$ & $-9,4$ & $-9,4$ & $-10,3$ & $-6,8$ & $-5,9$ & $-4,5$ & \\
\hline $\begin{array}{l}\text { Dług publiczny Polska (GG) } \\
\text { \% PKB }\end{array}$ & 47,1 & 50,9 & 55,1 & 56,4 & 55,6 & 57,1 & 50,2 & 51,1 & 54,4 \\
\hline $\begin{array}{l}\text { Dług publiczny Hiszpania } \\
\text { (GG) \% PKB }\end{array}$ & 40,2 & 53,9 & 66,3 & 69,5 & 85,4 & 93,7 & 99,3 & 99,0 & 98,98 \\
\hline $\begin{array}{l}\text { Udział długu samorządowego } \\
\text { w długu ogółem - Polska }\end{array}$ & 4,8 & 6,1 & 7,0 & 7,7 & 7,8 & 7,6 & 8,5 & 8,2 & 7,2 \\
\hline $\begin{array}{l}\text { Udział długu samorządowego } \\
\text { w długu ogółem - Hiszpania }\end{array}$ & 24,1 & 22,4 & 24,5 & 24,5 & 26,1 & 25,8 & 26,5 & 27,9 & \\
\hline
\end{tabular}

Źródło: [Eurostat 2016]. 
Dane wskazują, że w obu krajach w 2009 r. nastąpił gwałtowny spadek wartości wskaźnika fiskalizmu. W Hiszpanii od 2012 r. należy odnotować stały wzrost wartości tego wskaźnika. W 2015 r. wskaźnik jest znacząco wyższy od wartości z 2008 r. W Polsce miał miejsce systematyczny wzrost wskaźnika fiskalizmu, lecz o mniejszej dynamice. W 2015 r. wskaźnik był jednak nadal dużo niższy od poziomu z 2008 r. (1\% PKB w 2015 r. stanowił około 19 mld zł). Wskaźnik redystrybucji w 2009 r. w obu krajach wzrósł. Zdecydowanie wyższy przyrost był w Hiszpanii. W kolejnych latach w Polsce wartość wskaźnika redystrybucji systematycznie spadała, choć w 2014 r. wskaźnik ten utrzymał się na poziomie zbliżonym do $2013 \mathrm{r}$. W Hiszpanii gwałtowny wzrost wartości wskaźnika redystrybucji zauważyć można w 2012 r., w kolejnych latach ma miejsce systematyczny, znaczący spadek wartości tego wskaźnika.

Deficyt SIRziS w 2014 r. osiągnął w Polsce poziom poniżej 3\% PKB. W kolejnych latach następuje stabilizacja poziomu deficytu w relacji do PKB. Według metody ESA zmiany w OFE oszacowano na $0,4 \% \mathrm{PKB}$, co powoduje różnicę wartości deficytu obliczonego wg metody krajowej. W Hiszpanii znaczące wysiłki w kierunku obniżki wartości deficytu w relacji do PKB przyniosły efekty w 2013 r. Tendencja ta utrzymuje się w kolejnych latach. Prognozy wskazują jednak na trudności ze spełnieniem limitu deficytu poniżej 3\% PKB. Systematyczny spadek deficytu SIRziS w Polsce, przy niskim poziomie wartości wskaźnika fiskalizmu i wskaźnika redystrybucji PKB, sprzyja stabilnej wartości wskaźnika relacji długu do PKB. Gwałtowny spadek poziomu długu w Polsce miał miejsce w 2014 r. W Hiszpanii przy systematycznym, nieznacznym wzroście wartości wskaźnika fiskalizmu i przy równoczesnym znaczącym wzroście wskaźnika redystrybucji PKB, ma miejsce bardzo dynamiczny wzrost długu publicznego, z poziomu 40,2\% w 2008 r. do $99 \%$ w relacji do PKB w 2015 r.

\section{Wydatki według COFOG w Polsce i w Hiszpanii}

W tabelach 7 i 8 przedstawiono wydatki publiczne Polski i Hiszpanii, klasyfikowane wg funkcji COFOG za rok 2009 oraz za lata 2013-2015. Istotne zmiany w strukturze wydatków miały bowiem miejsce w latach 2013-2015.

W Polsce zmiany wynikały głównie z absorpcji środków UE na inwestycje oraz ze zmian w systemie OFE. Dodatkowe znaczenie miał wzrost nakładów na Obronę narodową oraz na Bezpieczeństwo i wymiar sprawiedliwości. Zmiany w systemie emerytalnym przyczyniły się nie tylko do zmniejszenia długu publicznego, lecz także do obniżki kosztów obsługi długu. Koszty te zaliczane są do funkcji Działalność ogólnopaństwowa. Umorzenie w 2014 r. 51,5\% obligacyjnej części aktywów zgromadzonych w OFE w kwocie $167 \mathrm{mld}$ zł (w tym koszty obsługi długu i pożyczki dla FUS) skutkowały istotną zmianą w strukturze wydatków wg COFOG. Udział funkcji Działalność ogólnopaństwowa w wydatkach ogółem wyniósł w 2013 r. $5,7 \%$, natomiast w 2014 r. 5,2\%. W 2015 r. nastąpił dalszy spadek wydatków na tę 
Tabela 7. Wydatki publiczne w Polsce według funkcji COFOG w latach 2009 oraz 2013-2015

\begin{tabular}{|l|r|r|r|r|}
\hline \multicolumn{1}{|c|}{ Rodzaj wydatków publicznych } & 2009 & 2013 & 2014 & 2015 \\
\hline 1. Działalność ogólnopaństwowa & 12,3 & 13,4 & 11,9 & 11,8 \\
\hline 2. Obrona narodowa & 3,4 & 3,9 & 3,5 & 3,8 \\
\hline 3. Bezpieczeństwo i porządek państwa & 5,3 & 5,2 & 5,3 & 5,3 \\
\hline 4. Sprawy gospodarcze & 12,5 & 10,1 & 11,0 & 11,1 \\
\hline 5. Ochrona środowiska & 1,6 & 1,5 & 2,1 & 1,5 \\
\hline 6. Gospodarka mieszkaniowa i komunalna & 1,3 & 1,0 & 1,7 & 1,7 \\
\hline 7. Ochrona zdrowia & 11,1 & 10,9 & 11,0 & 11,2 \\
\hline 8. Organizacja wypoczynku, kultura i religia & 2,9 & 2,7 & 2,8 & 2,7 \\
\hline 9. Edukacja & 12,0 & 12,4 & 12,5 & 12,6 \\
\hline 10. Ochrona socjalna & 36,5 & 38,3 & 38,2 & 38,3 \\
\hline 11. Wydatki ogółem & 100,0 & 100,0 & 100,0 & 100,0 \\
\hline
\end{tabular}

Źródło: http://appsso.eurostat.ec.europa.eu/nui/show.do?dataset=gov_10a_exp\&lang=en.

Tabela 8. Wydatki publiczne w Hiszpanii według funkcji COFOG w latach 2009 oraz 2013-2015

\begin{tabular}{|l|r|r|r|r|}
\hline \multicolumn{1}{|c|}{ Rodzaj wydatków publicznych } & 2009 & 2013 & 2014 & 2015 \\
\hline 1. Działalność ogólnopaństwowa & 12,3 & 15,9 & 15,6 & 14,8 \\
\hline 2. Obrona narodowa & 2,2 & 2,1 & 1,9 & 2,2 \\
\hline 3. Bezpieczeństwo i porządek państwa & 4,5 & 4,5 & 4,5 & 4,6 \\
\hline 4. Sprawy gospodarcze & 12,5 & 10,1 & 10,1 & 10,2 \\
\hline 5. Ochrona środowiska & 2,3 & 1,8 & 2,0 & 2,0 \\
\hline 6. Gospodarka mieszkaniowa i komunalna & 2,8 & 1,0 & 1,1 & 1,2 \\
\hline 7. Ochrona zdrowia & 14,8 & 12,9 & 13,6 & 14,1 \\
\hline 8. Organizacja wypoczynku, kultura i religia & 3,6 & 2,5 & 2,6 & 2,7 \\
\hline 9. Edukacja & 10,1 & 9,0 & 9,1 & 9,4 \\
\hline 10. Ochrona socjalna & 35,0 & 39,5 & 39,4 & 39,0 \\
\hline 11. Wydatki ogółem & 100,0 & 100,0 & 100,0 & 100,0 \\
\hline
\end{tabular}

Źródło: http://appsso.eurostat.ec.europa.eu/nui/show.do?dataset=gov_10a_exp\&lang=en.

funkcję. Poza kosztami obsługi długu zmiany w strukturze wydatków wynikały ze wzrostu nakładów na funkcje: Sprawy gospodarcze i Obrona narodowa. Funkcja Sprawy gospodarcze obejmuje nakłady na transport, rolnictwo, które odnotowały wzrost nakładów z budżetu środków europejskich.

Zmiany w strukturze wydatków Hiszpanii odnoszą się do znacznego zwiększenia wydatków na dwie funkcje, a mianowicie na Działalność ogólnopaństwową i na Ochronę socjalną. Recesja gospodarcza spowodowała wzrost bezrobocia, a zawirowania na rynku finansowym skutkowały wzrostem rentowności obligacji. Jak wskazano wcześniej, poziom długu od 2012 r. systematycznie rósł, obciążając budżet centralny i samorządowe wysokimi kosztami jego obsługi, które zaliczane są do działalności ogólnopaństwowej. 


\section{Zakończenie}

Wyniki przeprowadzonych analiz pokazują znaczne zróżnicowanie w obszarze regulacji prawnych, instytucji fiskalnych oraz w strukturze wydatków publicznych Polski i Hiszpanii wykorzystywanych w makrozarządzaniu stabilnością finansów publicznych. Polskę charakteryzuje wysoki poziom centralizacji władzy fiskalnej oraz restrykcyjne regulacje limitu długu, jak i skali zobowiązań w samorządach. Udział kosztów obsługi długu w wydatkach publicznych został obniżony, ale drogą zmian w systemie finansowania przyszłych emerytur. Skutkowało to pozytywnymi efektami z punktu widzenia zrównoważonej polityki fiskalnej. Hiszpania jest krajem, w którym zadanie zarządzania stabilnością fiskalną przypisane jest niezależnemu organowi fiskalnemu CPFF. Ustrój tery torialny charakteryzuje zaś duża autonomia samorządów, $\mathrm{z}$ punktu widzenia gospodarki finansowej. Wprawdzie przedstawiono duże trudności z procedurą nadmiernego deficytu w Hiszpanii, analiza aktów prawnych wykazała jednak duże nowe zmiany instytucjonalne oraz w regulacjach fiskalnych, zwiększających restrykcyjność norm odnoszących się do skali zobowiązań. Zmiany te potwierdzają wysoką rangę Paktu Fiskalnego oraz odpowiedzialne podejście władz UE do wieloaspektowej, indywidualnej oceny parametrów fiskalnych poszczególnych państw w świetle nie tylko stabilności budżetowej, lecz również w świetle koordynacji i zarządzania w UE.

\section{Literatura}

Alińska A., 2017, O potrzebie poszukiwania nowego paradygmatu stabilności systemu finansowego, [w:] Złota księga jubileuszowa dla profesora Jana Szczepańskiego z okazji odnowienia doktoratu, red. J. Ostaszewski, J. Ickiewicz, SGH, Warszawa.

Chojna-Duch E., 2017, Polityka stabilnościowa UE po globalnym kryzysie ekonomicznym - jej ograniczona skuteczność, [w:] Sektor finansów publicznych a rozwój gospodarczy. Problemy i dylematy, red. M. Żukowski, KUL, Lublin.

Cieślukowski M., 2017, Nauka o finansach publicznych $w$ świetle paradygmatu zrównoważonego rozwoju, Finanse, $\mathrm{nr} 1$.

Domínguez Martínez J.M., López Jiménez J.M., 2012, La reforma de la política de estabilidad presupuestaria en España: Análisis de la Ley Orgánica de Estabilidad Presupuestaria y Sostenibilidad Financiera, Instituto Universitario de Análisis Económico y Social, Universidad de Alcalá, Serie Documentos de Trabajo 2/2012.

Estrategia de Política Fiscal, 2018, http://www.minhafp.gob.es/Documentacion/Publico/CDI/EstrategiaPoliticaFiscal/Estrategia_Pol\%C3\%ADtica_Fiscal.pdf.

Eurostat, http://appsso.eurostat.ec.europa.eu/nui/show.do?dataset=gov_10a_exp\&lang=en

Eurostat 2016: Government revenue, expenditure and main aggregates.

Femia Julve L.C., 2015, Un lustro de consolidación normativa en materia de estabilidad presupuestaria en España. Análisis crítico, balance y perspectivas de futuro, Foro, Nueva época, vol. 18, núm. 1, s. 3. 
Fiedor B., Scheuer B., Dokurno Z., 2016, Paradygmat zrównoważonego rozwoju a współczesna makroekonomia-ujęcie epistemologiczne, Ekonomista, nr 1.

Gospodarka finansowa jednostek samorządu terytorialnego $2016 \mathrm{r}$.

Marczak J., 2013, Stan finansów publicznych Hiszpanii po wejściu do strefy euro, [w:] Przyszłość Unii Europejskiej w świetle ustroju walutowego i finansowego, red. C. Kosikowski, Temida 2, Białystok, s. 39.

Osiatyński J., 2016, Quo vadis euro - Unio? Perspektywa ekonomii postkeynesowskiej, Ekonomista, nr 3.

Ratajczak M., 2017, Liberalizm i neoliberalizm ekonomiczny w perspektywie historycznej, Ekonomista, nr 1.

Redo M., 2017, Niekeynesowska zależność pomiędzy tempem wzrostu gospodarczego a wielkościa dochodów $i$ wydatków publicznych $w$ relacji do PKB w latach 2001-2015 w 11 państwach Europy Środkowo-Wschodniej należacych do Unii Europejskiej, Finanse, nr 1.

Ruiz Martí V., 2015, Las políticas fiscales en España. Efectos sobre el déficit presupuestario, Universitat de Politécnica de Valéncia, Valencia, http://hdl.handle.net/10251/55745.

Sukiennik J., Dokurno Z., Fiedor B., 2017, System instytucjonalnej równowagi a proces zmian instytucjonalnych z perspektywy zrównoważonego rozwoju, Ekonomista, nr 2.

Uryszek T., 2016, Primary deficit indicator, tax gap, fiscal sustainability - evidence from Central and Eastern EU member states, Finanse, nr 9.

Ustawa 18/2001 z 12 grudnia 2001 r. o Stabilności Budżetowej, BOE, nr 298 z 13 grudnia 2001 r. (Ley 18/2001de 12 de diciembre, General de Estabilidad Presupuestaria, BOE núm. 298, de13 de diciembre de 2001).

Ustawa organiczna 8/1980 z 22 września o finansowaniu wspólnot autonomicznych - la Ley Orgánica 8/1980, de 22 de septiembre, de Financiación de las Comunidades Autónomas (LOFCA).

Ustawa organiczna 2/2012 z 27 kwietnia o Stabilności Budżetowej i Równowadze Finansowej, BOE, nr 103 z 30 kwietnia 2012 r., tekst jednolity (Ley Orgánica 2/2012, de 27 de abril, de Estabilidad Presupuestaria y Sostenibilidad Financiera. BOE núm. 103, de 30 de abril de 2012).

Ustawa organiczna nr 6/2013 z 14 listopada o utworzeniu Niezależnego Urzędu ds. Odpowiedzialności Fiskalnej, BOE, nr 274 z 15 listopada 2013 r. (Ley Orgánica 6/2013, de 14 de noviembre, de creación de la Autoridad Independiente de Responsabilidad Fiscal, BOE núm. 274, de 15/11/2013).

Ustawa o finansach publicznych z dnia 27 sierpnia 2009 r., Dz.U. z 2009, nr 57, poz. 1240. 